\title{
The health impact of (sexual) torture amongst Afghan, Iranian and Kurdish refugees: A literature review
}

\author{
Roghieh Dehghan*
}

\section{Key points of interest}

- Despite the high prevalence of torture in Iran, Afghanistan and the geo-cultural region of Kurdistan, there is a lack of healthrelated research on this population. This is particularly true for Afghans.

- There is no health research on sexual torture focused on Afghan, Iranian and Kurdish survivors.

- Culture, gender and sexuality mediate the embodied experience of trauma. Therefore, they need to be more than a mere 'footnote' in trauma research.

\begin{abstract}
Background: Amongst Muslim majority countries, torture is reported most in Afghanistan and Iran. In addition, despite the significant impact of sexual violence on individuals and public health, the issue has been poorly researched amongst victims of torture. Objectives: The original intention of this paper was to review the health impact of sexual torture amongst Iranian and Afghan refugees in high-income countries; however,
\end{abstract}

a comprehensive search of relevant databases did not produce any results. The aim of this review was then altered to examine those health-related studies that explored the impact of torture in this population. Special attention was given to the discussion of gender and sexual violence in those studies. Methodology: Web of Science, PILOTS, Medline, PsycINFO, Scopus, Popline and the online catalogue at DIGNITY were searched for health studies that examined the health impact or predictors of adverse health outcomes in Afghan, Iranian and Kurdish refugee survivors of torture. Outcome: Seven papers were identified and examined in this review. The results were limited by the diverse methodologies, by the use of psychiatric tools that had not been validated in this population, and by small sample sizes. Since there is a high prevalence of sexual torture in Iranian and Kurdish refugees, the issue merits greater attention in this population. Studies are most limited amongst the Afghan population. Moreover, there is a great need for further culture-andgender-specific health research in torture survivors from Muslim backgrounds.

Keywords: Sexual torture, health, Muslims, refugees

\section{Introduction}

The United Nation High Commissioner for 
Refugees (UNHCR) ${ }^{1}$ estimates that $15 \%$ of the 25.4 million refugees worldwide try to settle in developed countries. Many of them have experienced various types of trauma, trauma, torture being amongst them.

Torture can result in a plethora of physical problems, including shame, guilt, social withdrawal, substance abuse as well as a variety of mental health problems (Isakson \& Jurkovic, 2013). A large systematic review and meta-analysis undertaken by Steel et al. (2009) that included 81,866 refugees from 40 countries found that torture was associated with $23.6 \%$ cases of posttraumatic stress disorders (PTSD) and 14\% of depression.

While reports on the prevalence of torture in asylum seekers vary widely, estimates range from $30 \%$ to $84 \%$ (Duffy et al., 2016, Kalt et al., 2013). Similarly, sexual torture is reported by $63 \%-80 \%$ of female and $25 \%-56 \%$ of male torture survivors in high-income countries (Busch et al., 2015; Lunde \& Ortmann, 1990). The 1984 UN Convention against Torture regards sexual torture as any sexual offence conducted by or at the direction of official authorities that results in mental and physical suffering. ${ }^{2,3}$ It is reasonable to assume that the actual rates of sexual torture are higher than estimated since it is well known that sexual violence is either never explicitly admitted to or is disclosed late (Leatherman, 2011, Peel, 2004; Oosterhoff, 2004; Patel \& Mahtani, 2004).

12017 in Review - Trends at a Glance: http://www. unhcr.org/5b27be547.pdf

2 Convention against Torture and Other Cruel, Inhuman or Degrading Treatment or Punishment. United Nations General Assembly: http://www. un.org/documents/ga/res/39/a39r046.htm

3 Many scholars have contested the UN definition of torture. See for example V. Canning (2015).
This silence surrounding sexual torture is worth our attention. There is little doubt that the physical and psychological methods and the impact of all forms of torture are impossible to decouple. Yet, there seems to be something unique about sexual torture that leads to a level of stigmatisation and silence far beyond other forms of torture (Canning, 2015; Sansani, 2004). One explanation that has been offered is that no other type of violence targets the individual's identity and sense of a coherent self in the same way that sexual violence does (Agger, 1989). The 'self' we are referring to, however, is a cultured and gendered entity in a sociopolitical context.

There is indeed some evidence for this context-dependent impact of torture. Cross-cultural research acknowledges a link between the response to a traumatic event and socio-cultural factors (Jobson 2009; Summerfield, 1999). After all, people's values, attitudes and behaviours and the way they perceive the social world determine their experience (Berry et al,1992). For instance, it is suggested that the subjective perception of the severity of torture and the sense of loss of control correspond with mental health outcomes in survivors (Basoglu \& Parker, 1995). Further, Leaman's and Gee's (2012) analysis of 131 African torture survivors in the U.S. illustrates that 'positive religious coping' is a protective factor from adverse mental health outcomes in relation to physical torture. This, however, does not hold true for sexual torture. In contrast, another recent U.S. study by Song and colleagues (2015) reveals that being of Muslim faith is one of the characteristics associated with adverse mental health outcomes in tortured refugees. Culture, religious/political affiliations, and sociodemographic variables impact individual and societal responses to sexual 
assault (Burt, 1980; Suarez \& Gadalla, 2010). It is however clear that both gender and sexual torture have received far too little attention in academia.

Gender is not only an identity marker but also a "social structure" that places people, relationships and human activities in hierarchical categories in a manner symbolically associated with masculinity and femininity (Mazurana \& Proctor, 2013, p. 2). Seen in this light, it becomes evident that men and women, having been exposed to different cultural messages, will appraise and interpret sexual violence, which is an attack on their sense of "private" and "social" self, differently (Sansani, 2004, p. 352). It also seems likely that the multiplicity of traumatic experiences-polyvictimisation-influences the prevalence of PTSD in tortured refugees (Young \& Chan, 2015, p. 26). Unsurprisingly, polytraumtisation is more prevalent among female refugees (Kastrup \& Arcel, 2004; Kira \& Tummala-Narra, 2015). Having interviewed 160 women at a centre for treatment of torture survivors, Kira et al. (2010) argue that while gender discrimination is not directly associated with PTSD, being female increases the risk of PTSD through a direct increase of cumulative traumatogenic dynamics, stressors that predispose an individual to respond differently to new traumas. Tellingly, an evaluation of the literature related to health and refugees suggests a higher rate of mental health disorders in female refugees compared to male refugees (Hollander et al., 2011); however, the relationship between gender and psychopathology after trauma remains inconsistent and contradictory. In 2008, a review of predictors of PTSD in survivors of war and torture by Johnson and Thompson found female gender to be a risk factor. It is important to note that this finding was not replicated in the systematic review of Bogic et al. (2015), which investigated the long-term mental health effects of war trauma. Still, their research uncovered a higher prevalence of anxiety in women.

Taking all the above into consideration and bearing in mind the significant number of torture survivors from Muslim-majority countries such as Afghanistan and Iran, ${ }^{4}$ it is striking that health-related research on sexual torture in this population is largely absent from the main corpus of academic literature. A recent systematic review of health impacts of war-related sexual violence (not sexual torture specifically) from 1981 to 2014 identified just 18 papers from five sub-Saharan countries and two papers on Croatia (Ba \& Bhopal, 2017). It is important to recognise that this time period coincides with the Iranian revolution, the Iran-Iraq war, the conflict in Afghanistan as well as the ongoing Israel-Palestine conflict, a dispute where sexual assault has been reported on Palestinian men by Israeli authorities (Weishut, 2015). Similarly, publications by the organisations Justice for $\operatorname{Iran}^{5}$ and the Iran Human Rights Documentation Center ${ }^{6}$ detail hundreds of testimonies indicating a high prevalence of rape of women in the prisons of the Islamic Republic of Iran. Even so, research often treats sexual torture in Muslim countries as a mere 'footnote' or frames it within a human rights and international relations perspective rather than a dynamic founded in health care.

4 Where does torture happen? www.freedomfromtorture.org/page/where_does_torture_happen

5 Justice for Iran: http://justice4iran.org/category/ publication/. See especially: "Raped out of Paradise: Women in Prisons of the Islamic Republic of Iran" (June 2013)

6 Reports by Iran Human Rights Documentation Center: http://www.iranhrdc.org/english/publications/reports/index.1.html 


\section{Purpose of the review}

In order to address this gap in the research and respond to evidence that supports a link between the impact of trauma and a victim's socio-cultural background, this review initially intended to investigate the reported health effects of sexual torture amongst Afghans and Iranians; Kurdish survivors were also included since Iran has a substantial Kurdish population. While some Kurdish refugees may have originated from Iraq, Syria or Turkey, those countries were omitted to limit the socio-cultural diversity of the participants. However, a search through the main health databases produced no health-related results on sexual torture. It was therefore decided to broaden the topic to examine health-related literature covering torture in general in Afghan, Iranian or Kurdish asylum seekers/ refugees. Special attention was paid to discussions of sexual violence or gender in the studies. This review therefore focuses on papers that study Afghan, Iranian or Kurdish torture survivors and:

1) report on the health impacts of torture in general;

2) or discuss the predictors of the adverse health outcomes.

\section{Methods}

\section{Selection criteria}

Studies were eligible for inclusion in this review if they: (1) reported on Afghan, Iranian or Kurdish refugees in high-income countries; (2) presented data on refugees from these groups who were torture survivors; and (3) explored the physical/ mental health impact of such torture. Case reports, editorials, opinions and discussions investigating the effectiveness of particular interventions and studies measuring the sensitivity of a psychological tool were excluded. Studies that examined refugees as a general population, rather than specifying their ethnic/national background, or focused on a diverse range of traumas, such as soldiers from conflict zones, were also excluded.

\section{Search strategy}

Web of Science, PILOTS, Medline, PsycINFO and Scopus were searched using subject headings (e.g. mental disorders, refugees, emigrants, sex offence, rape, torture) and keywords (e.g. PTSD, migrants, displaced persons, sexual violence). Papers from Popline were also added by searching for refugees and torture. Additionally, the online catalogue at DIGNITY ${ }^{7-}$ Danish Institute Against Torture Documentation Centre and Library-was examined separately for items indexed with the term 'sexual torture'. Due to language barriers, only papers in English, Persian and Dari were included. No Kurdish papers were found. The search considered refugees to any countries and there was no date limit applied.

\section{Data extraction and analysis}

After removing duplicates, 114 studies were identified in the main databases and 235 more in the library of DIGNITY. Their titles and abstracts were examined against the inclusion criteria. When a review of the abstract of a paper did not clarify its relevance, the study was retrieved and reviewed in full text. Ultimately, a total of seven papers met the review criteria and their information on study design, participants, setting, measurement tools and outcomes were extracted and summarised (see Table 1).

7 DIGNITY is a Danish Human Rights Institute specialising in clinical and research work on torture at an international level. 
Most studies included participants from more than one country; therefore, studies were only included where the nationalities of participants were explicit and a substantial number of them (set at one-third as expecting a higher number was unrealistic and a lower figure was considered insignificant) were Afghans, Iranians or Kurds.

As outlined in Figure 1 (see Appendix 1), following the initial screening, 97 studies from the main databases were excluded on the basis of their abstracts. After examining the full texts of the remaining 17 papers, six were retained for inclusion in this review. Of the 11 papers that were removed, two did not report on torture survivors, five included a heterogeneous group with insufficient participation by the cohort of interest, two were single case reports, and two investigated interventions.

All 235 papers from DIGNITY were examined individually, and after discarding those studies with a human rights rather than a health or medical framework, only one paper was retained. This resulted in a total of seven papers that are included in the review.

\section{Findings}

Table 1 summarises the main findings of this review.

\section{Description of selected studies}

Of the seven papers included, four were conducted in Scandinavian countries, predominantly in Denmark (three), while the other two locations were Germany (one) and the United Kingdom (two). Four study designs were cross-sectional, one longitudinal and two were case-file reviews. Three studies recruited only Iranian refugees, and one study exclusively focused on Kurdish torture survivors (both from Freedom from Torture (FFT) in the UK); the remaining studies had an ethnically mixed group. Sample sizes ranged from 17 to 139 .

\section{Health outcomes and measurement}

The papers measured physical and mental health outcomes, predictors of mental health, and the functional impairment that can occur as a result of torture. A diverse methodology was used (see Table 1). The symptoms of PTSD were defined through the Diagnostic and Statistical Manual of Mental Disorders (DSM).

The two studies conducted at FFT (Bradley \& Tawfiq, 2006; FFT, 2013) reviewed records of comprehensive interviews conducted by doctors trained to recognise symptoms of torture in accordance with the Istanbul Protocol. ${ }^{8}$ Within this context, depression, anxiety and PTSD were defined according to the DSM criteria. In the five other studies, various psychometric tools were used to supplement interviews; apart from the two studies undertaken by Morville et al. (2014, 2015), different instruments were used in the studies. The following well-known questionnaires were utilised to measure trauma, anxiety and depression: self-reported questionnaires such as the HTQ (Harvard Trauma Questionnaire), ${ }^{9}$ Hopkin Symptom Checklist-25 (HSCL-25), ${ }^{10}$ the Hamilton Rating Scale for Depression (HAMD) ${ }^{11}$

8 Istanbul Protocol is an official UN manual for examination and documentation of torture. See http://www.ohchr.org/Documents/Publications/ training8Rev1 en.pdf

9 See Harvard Programme in Refugee Trauma for full questionnaire: http://hprt-cambridge.org/ screening/harvard-trauma-questionnaire/

10 Ibid. http://hprt-cambridge.org/screening/hopkins-symptom-checklist/

11 Ibid. http://hprt-cambridge.org/screening/hopkins-symptom-checklist/ 
Table 1: Summary of main findings

\begin{tabular}{|c|c|c|c|c|c|c|}
\hline Author & $\begin{array}{l}\text { Title of } \\
\text { publica- } \\
\text { tion }\end{array}$ & $\begin{array}{l}\text { Study } \\
\text { site }\end{array}$ & Measurements & $\begin{array}{l}\text { Study } \\
\text { design and } \\
\text { sampling }\end{array}$ & $\begin{array}{l}\text { Health } \\
\text { outcome }\end{array}$ & $\begin{array}{l}\text { Predictors of } \\
\text { health outcome }\end{array}$ \\
\hline $\begin{array}{l}\text { Priebe } \\
\& \text { Es- } \\
\text { maili } \\
1997\end{array}$ & $\begin{array}{l}\text { Long- } \\
\text { Term } \\
\text { Mental } \\
\text { Seque- } \\
\text { lae of } \\
\text { Torture in } \\
\text { Iran-Who } \\
\text { Seeks } \\
\text { Treat- } \\
\text { ment? }\end{array}$ & $\begin{array}{l}\text { Ger- } \\
\text { many }\end{array}$ & $\begin{array}{l}\text { Interviews } \\
\text { Symptoms self-rated } \\
\text { on the full 65-item } \\
\text { version of the von } \\
\text { Zerssen } \\
\text { Complaints } \\
\text { Observer ratings of } \\
\text { psychopathology } \\
\text { (Hamilton Rating } \\
\text { Scale for Depres- } \\
\text { sion (HAMD) and } \\
\text { the Hamilton Rating } \\
\text { Scale for Anxiety } \\
\text { (HAMA) } \\
\text { PTSD-symptoms as } \\
\text { defined in DSM-III }\end{array}$ & $\begin{array}{l}\text { Cross- } \\
\text { sectional } \\
\text { Purposive } \\
\text { sampling } \\
\mathrm{N}=34 \text { Ira- } \\
\text { nian torture } \\
\text { survivors }\end{array}$ & PTSD: $53 \%$ & $\begin{array}{l}\text { Poor language } \\
\text { skills and PTSD } \\
\text { symptoms of } \\
\text { arousal and intru- } \\
\text { sion associated } \\
\text { with therapy-seek- } \\
\text { ing behavior }\end{array}$ \\
\hline $\begin{array}{l}\text { Ghaz- } \\
\text { inour et } \\
\text { al. } \\
(2003)\end{array}$ & $\begin{array}{l}\text { Personali- } \\
\text { ty Related } \\
\text { to Coping } \\
\text { and Social } \\
\text { Support } \\
\text { Among } \\
\text { Iranian } \\
\text { Refugees } \\
\text { in Swe- } \\
\text { den. }\end{array}$ & $\begin{array}{l}\text { Swe- } \\
\text { den }\end{array}$ & $\begin{array}{l}\text { Beck Depression } \\
\text { Inventory (BDI) } \\
\text { Temperament and } \\
\text { Character Inventory } \\
\text { (TCI) } \\
\text { The Coping Resourc- } \\
\text { es Inventory } \\
\text { Schedule of Social } \\
\text { Interaction Symp- } \\
\text { tom-Checklist- } 90 \\
\text { (SCL-90-R) } \\
\text { Global Severity Index } \\
\text { (GSI) } \\
\text { Pos. Symptom Total } \\
\text { (PST) } \\
\text { Pos. Symptom Dis- } \\
\text { tress Index (PSDI) }\end{array}$ & $\begin{array}{l}\text { Cross- } \\
\text { sectional } \\
\text { Conveni- } \\
\text { ence sam- } \\
\text { pling. } \\
\mathrm{N}=100 \\
\text { Iranian } \\
\text { refugees } \\
\text { (Soldiers } \\
45 \% \\
\text { Prisoners } \\
\text { and } \\
\text { Tortured } \\
\text { victims } \\
25 \% \\
+ \text { civilians } \\
\text { in war) }\end{array}$ & & $\begin{array}{l}\text { Good social } \\
\text { support, being } \\
\text { self-directed and } \\
\text { not harm-avoidant } \\
\text { and being female } \\
\text { associated with } \\
\text { less psychopatho- } \\
\text { logical disorders }\end{array}$ \\
\hline $\begin{array}{l}\text { Brad- } \\
\text { ley \& } \\
\text { Tawfiq } \\
(2006)\end{array}$ & $\begin{array}{l}\text { The } \\
\text { Physical } \\
\text { and Psy- } \\
\text { chological } \\
\text { Effects of } \\
\text { Torture } \\
\text { in Kurds } \\
\text { Seeking } \\
\text { Asylum } \\
\text { in the } \\
\text { United } \\
\text { Kingdom }\end{array}$ & $\begin{array}{l}\text { UK } \\
\text { FFT }\end{array}$ & $\begin{array}{l}\text { Records, interviews } \\
\text { and examination with } \\
\text { interpreter }\end{array}$ & $\begin{array}{l}\text { Retrospec- } \\
\text { tive Case } \\
\text { file review } \\
97 \text { Kurdish } \\
\text { torture } \\
\text { survivors }\end{array}$ & $\begin{array}{l}\text { PTSD: } 14 \% \\
\text { Anxiety: } 7 \% \\
\text { Major de- } \\
\text { pression: } 7 \% \\
\text { Chronic } \\
\text { pain: } 22 \% \\
\text { Sexual as- } \\
\text { sault: } 30 \% \text { of } \\
\text { women }\end{array}$ & $\begin{array}{l}\text { No association } \\
\text { between chronic } \\
\text { pain and psycho- } \\
\text { logical problems } \\
\text { No association } \\
\text { between sexual as- } \\
\text { sault and psycho- } \\
\text { logical problems } \\
\text { Association } \\
\text { between reporting } \\
\text { sexual torture and } \\
\text { female gender } \\
\text { No association be- } \\
\text { tween gender and } \\
\text { psychopathology }\end{array}$ \\
\hline
\end{tabular}




\begin{tabular}{|c|c|c|c|c|c|c|}
\hline Author & $\begin{array}{l}\text { Title of } \\
\text { publica- } \\
\text { tion }\end{array}$ & $\begin{array}{l}\text { Study } \\
\text { site }\end{array}$ & Measurements & $\begin{array}{l}\text { Study } \\
\text { design and } \\
\text { sampling }\end{array}$ & $\begin{array}{l}\text { Health } \\
\text { outcome }\end{array}$ & $\begin{array}{l}\text { Predictors of } \\
\text { health outcome }\end{array}$ \\
\hline $\begin{array}{l}\text { Carlson } \\
\text { et al. } \\
(2006)\end{array}$ & $\begin{array}{l}\text { Mental } \\
\text { Health } \\
\text { and } \\
\text { Health- } \\
\text { Related } \\
\text { Quality of } \\
\text { Life } \\
\text { A 10-Year } \\
\text { Follow- } \\
\text { Up of } \\
\text { Tortured } \\
\text { Refugees }\end{array}$ & $\begin{array}{l}\text { Den- } \\
\text { mark } \\
\text { Reha- } \\
\text { bili- } \\
\text { tation } \\
\text { and } \\
\text { Re- } \\
\text { search } \\
\text { Cen- } \\
\text { tre for } \\
\text { Tor- } \\
\text { ture } \\
\text { Vic- } \\
\text { tims }\end{array}$ & $\begin{array}{l}\text { Interviews } \\
\text { Harvard Trauma } \\
\text { Questionnaire } \\
\text { (HTQ) } \\
\text { HSCL-25 Hopkin } \\
\text { Symptom check- } \\
\text { list-25 (HSCL-25) }\end{array}$ & $\begin{array}{l}\text { Longitudi- } \\
\text { nal study } \\
\text { All new pa- } \\
\text { tients from } \\
1991-1994 . \\
\text { Follow-up } \\
\text { conducted } \\
\text { in } 2002- \\
2003 \\
\text { N= } 139 \\
(126 \text { men } \\
\text { and } 13 \\
\text { women) } \\
33.7 \% \\
\text { Iranians } \\
29.5 \% \text { Ira- } \\
\text { qis, } 18.7 \% \\
\text { Lebanese. } \\
63.8 \% \\
\text { Muslims }\end{array}$ & $\begin{array}{l}\text { PTSD: } \\
56.1 \% \\
\text { Depression: } \\
69.1 \%\end{array}$ & $\begin{array}{l}\text { Time factor: After } \\
10 \text { years } \\
\text { Health-related } \\
\text { quality of life and } \\
\text { mental health } \\
\text { symptoms im- } \\
\text { proved } \\
\text { Physical pain: the } \\
\text { main predictor } \\
\text { of mental health } \\
\text { symptoms at } \\
\text { baseline but not } \\
\text { long-term } \\
\text { Long-term, the } \\
\text { main factors } \\
\text { associated with } \\
\text { emotional distress } \\
\text { and poor quality } \\
\text { of life were poor } \\
\text { social support and } \\
\text { unemployment } \\
\text { Higher education } \\
\text { levels were linked } \\
\text { with increased } \\
\text { anxiety }\end{array}$ \\
\hline $\begin{array}{l}\text { FFT } \\
\text { Coun- } \\
\text { try } \\
\text { report } \\
(2013)\end{array}$ & $\begin{array}{l}\text { We will } \\
\text { make you } \\
\text { regret } \\
\text { every- } \\
\text { thing: } \\
\text { Torture in } \\
\text { Iran since } \\
\text { the } 2009 \\
\text { election. } \\
\text { Freedom } \\
\text { from } \\
\text { Torture } \\
\text { Country } \\
\text { Reporting }\end{array}$ & $\begin{array}{l}\text { UK } \\
\text { FFT }\end{array}$ & $\begin{array}{l}\text { Detailed forensic } \\
\text { evidence obtained } \\
\text { for medico-legal } \\
\text { reports }\end{array}$ & $\begin{array}{l}\text { System- } \\
\text { atic Case } \\
\text { Review } \\
\text { A total of } \\
50 \text { clients } \\
\text { ( } 40 \text { men } \\
\text { and } 10 \\
\text { women) } \\
\text { who had } \\
\text { been de- } \\
\text { tained and } \\
\text { tortured } \\
\text { from } 2009 \\
\text { onwards } \\
\text { and had } \\
\text { given } \\
\text { consent for } \\
\text { research. }\end{array}$ & $\begin{array}{l}\text { Sexual tor- } \\
\text { ture in } 60 \% \\
\text { of the clients } \\
\text { (n=6 women, } \\
n=24 \text { men) } \\
\text { Chronic } \\
\text { pain: } 48 \% \\
\text { PTSD: } 90 \% \\
\text { (n=45) } \\
\text { Depression: } \\
54 \% \text { ( }=27 \text { ) } \\
\text { Suicidal } \\
\text { ideation: } \\
54 \% \text { ( } n=27 \text { ) } \\
\text { Self-harm: } \\
20 \% \text { ( } n=10 \text { ) } \\
\text { Attempted } \\
\text { suicide: } 12 \% \\
\text { (n=6) }\end{array}$ & $\begin{array}{l}\text { Gender not } \\
\text { associated with } \\
\text { prevalence of } \\
\text { sexual torture }\end{array}$ \\
\hline
\end{tabular}




\begin{tabular}{|c|c|c|c|c|c|c|}
\hline Author & $\begin{array}{l}\text { Title of } \\
\text { publica- } \\
\text { tion }\end{array}$ & $\begin{array}{l}\text { Study } \\
\text { site }\end{array}$ & Measurements & $\begin{array}{l}\text { Study } \\
\text { design and } \\
\text { sampling }\end{array}$ & $\begin{array}{l}\text { Health } \\
\text { outcome }\end{array}$ & $\begin{array}{l}\text { Predictors of } \\
\text { health outcome }\end{array}$ \\
\hline $\begin{array}{l}\text { Mor- } \\
\text { ville et } \\
\text { al. } \\
(2014)\end{array}$ & $\begin{array}{l}\text { Activity of } \\
\text { Daily Liv- } \\
\text { ing Per- } \\
\text { formance } \\
\text { amongst } \\
\text { Danish } \\
\text { Asylum } \\
\text { Seekers: A } \\
\text { cross- } \\
\text { sectional } \\
\text { study }\end{array}$ & $\begin{array}{l}\text { Den- } \\
\text { mark } \\
\text { Asy- } \\
\text { lum } \\
\text { cen- } \\
\text { tres }\end{array}$ & $\begin{array}{l}\text { Observation-based } \\
\text { test assessment of } \\
\text { motor \& process } \\
\text { skills } \\
\text { Interviews using } \\
\text { WHO wellbeing } \\
\text { index } \\
\text { Major Depression } \\
\text { inventory (MDI) } \\
\text { pain detect ques- } \\
\text { tionnaire (PDQ) for } \\
\text { neuropathic pain } \\
\text { Self-rated Health } \\
\text { (SRH) } \\
\text { Activities of daily } \\
\text { living measured } \\
\text { (ADL) and AMPS= } \\
\text { Assessment of } \\
\text { Motor and Process } \\
\text { Skills (AMPS) } \\
\text { Telephone inter- } \\
\text { preters used }\end{array}$ & $\begin{array}{l}\text { Cross- } \\
\text { sectional } \\
\text { study } \\
\text { All new } \\
\text { asylum } \\
\text { seekers } \\
\text { from Feb to } \\
\text { June } 2011 \\
\text { recruited. } \\
\text { Identified } \\
\text { through } \\
\text { Danish Red } \\
\text { Cross } \\
\text { N= 43 (36 } \\
\text { male, } 7 \\
\text { female) } \\
\text { Iran (42\%), } \\
\text { Afghanistan } \\
\text { (39\%) and } \\
\text { Syria } \\
77 \% \text { tor- } \\
\text { tured } \\
\text { Participants }\end{array}$ & $\begin{array}{l}\text { Severe } \\
\text { depression: } \\
37 \% \\
\text { Moderate } \\
\text { depression: } \\
16 \% \\
\text { Mild depres- } \\
\text { sion: } 12 \% \\
\text { Impaired } \\
\text { Physical } \\
\text { and mental } \\
\text { health } \\
\text { Activities of } \\
\text { daily Liv- } \\
\text { ing (ADL) } \\
\text { compared } \\
\text { to general } \\
\text { population } \\
35 \% \text { reduc- } \\
\text { tion in ADL } \\
\text { process skills } \\
27 \% \text { reduc- } \\
\text { tion in ADL } \\
\text { motor skills }\end{array}$ & $\begin{array}{l}\text { Statistically } \\
\text { significant cor- } \\
\text { relation between } \\
\text { ADL competency } \\
\text { and pain as well } \\
\text { as psychological } \\
\text { distress, but no } \\
\text { difference between } \\
\text { tortured and non- } \\
\text { tortured asylum } \\
\text { seekers }\end{array}$ \\
\hline $\begin{array}{l}\text { Mor- } \\
\text { ville et } \\
\text { al. } \\
(2015)\end{array}$ & $\begin{array}{l}\text { A Lon- } \\
\text { gitudinal } \\
\text { Study of } \\
\text { Changes } \\
\text { in Asylum } \\
\text { Seekers } \\
\text { Ability } \\
\text { Regarding } \\
\text { Activities } \\
\text { of Daily } \\
\text { Living } \\
\text { During } \\
\text { Their } \\
\text { Stay } \\
\text { in the } \\
\text { Asylum } \\
\text { Center }\end{array}$ & $\begin{array}{l}\text { Den- } \\
\text { mark } \\
\text { Asy- } \\
\text { lum } \\
\text { cen- } \\
\text { tres }\end{array}$ & $\begin{array}{l}\text { Interview, question- } \\
\text { naire as Morville } \\
(2014)\end{array}$ & $\begin{array}{l}\text { Cross- } \\
\text { sectional } \\
\text { study } \\
\text { Partici- } \\
\text { pants from } \\
\text { previous } \\
\text { research } \\
\text { (Moville, } \\
2014 \text { ) } \\
\mathrm{N}=17 \text { (3 } \\
\text { women and } \\
\text { 14 men) } \\
\text { Iranian: } \\
\mathrm{n}=8 \\
\text { Afghani- } \\
\text { stan: } \mathrm{n}=6 \\
\text { Syrians: } \\
\mathrm{n}=3 \\
\text { Asylum } \\
\text { seekers, } \\
\text { mainly } \\
\text { torture } \\
\text { survivors } \\
\text { (n=14) }\end{array}$ & $\begin{array}{l}\text { Pain: } 72 \% \text { in } \\
\text { tortured and } \\
\text { non-tortured } \\
\text { refugees }\end{array}$ & $\begin{array}{l}\text { Decrease in ADL- } \\
\text { ability (see above) } \\
\text { and an increase in } \\
\text { pain and mental } \\
\text { health problems } \\
\text { after } 10 \text { months }\end{array}$ \\
\hline
\end{tabular}


and Anxiety (HAMA), ${ }^{12}$ Beck Depression Inventory (BDI), ${ }^{13}$ and the Major Depression Inventory (MDI). ${ }^{14}$

Morville et al. $(2014,2015)$ also collected data on the impairment of Activities of Daily Living (ADL) such as household chores, management of money, and social relations. ADL-ability was measured using Assessment of Motor and Process Skills (AMPS). This is a tool which has been standardised cross-culturally on more than 150,000 individuals. It evaluates problems in terms of motor functions (moving self and objects) and processes (organising and adapting actions).

Only Carlsson et al. (2006) reported on translating and back-translating the questionnaires into the respondents' native languages. They also operated WHO Quality of Life-BREF (WHOQOLBref), a cross-culturally applicable tool for the assessment of quality of life that comprises psychological, physical, social and environmental factors. ${ }^{15}$ Questionnaires used by Ghazinour et al. (2003) were all self-reported and in Swedish because of the linguistic skills of the Iranian participants.

To synthesise data stemming from diverse outcome measures and different categories, the discussion of results is divided into two sections that are based on the main topics covered in the papers. In the first part, the focus will be the health outcomes of torture

12 See http://www.assessmentpsychology.com/HAMA.pdf

13 See http://www.apa.org/pi/about/publications/ caregivers/practice-settings/assessment/tools/beckdepression.aspx

14 See https://psychology-tools.com/major-depression-inventory/

15 See WHOQOL-Bref at http://www.who.int/mental_health/media/en/76.pdf victims, and in the second section, the predictors of mental health will be explored.

\section{Health impacts of torture}

Six papers provided prevalence rates of PTSD, but only four discussed other health impacts of torture, such as chronic pain, impairment of ADL, depression, anxiety, and suicidal ideation and attempts (see Table 1).

The evidence for the pervasiveness of psychopathology in survivors of torture was considerable; however, the prevalence rates varied widely: PTSD $(14 \%-90 \%)$, anxiety $(7 \%)$ and depression $(7 \%-69.1 \%)$. The highest PTSD rates came from a Country Report for the UN Special Rapporteur on the status of human rights in Iran (FFT, 2013). This report was informed by a systematic case review of 50 forensic medico-legal reports (40 male and 10 female). Most clients were urban, welleducated and skilled professionals. 54\% $(n=27)$ of them had suicidal ideations. Attempted suicide was reported in $12 \%$ $(n=6)$ and self-harm in $20 \%(n=10)$. The prevalence of sexual torture for Kurdish and Iranian clients at FFT was, respectively, $30 \%-60 \%$ for women and $1 \%-60 \%$ for men (Bradley \& Tawfiq, 2006, FFT, 2013).

Morville et al's $(2014,2015)$ papers indicated a reduction of $35 \%$ in ADL process skills and $27 \%$ in ADL motor capabilities in traumatised asylum seekers compared to the general population. In addition, $72 \%$ of their participants suffered from pain $(n=31)$ with headache being the most prevalent site. Neuropathic pain was present in $9 \%(n=4)$. In comparison, the prevalence of chronic pain in FFT clients was significantly lower at $48 \%$ for Iranian victims (FFT, 2013) and $22 \%$ for Kurdish participants (Bradly \& Tawfiq 2006). 12\% were disabled due to their physical injuries. 


\section{Predictors of adverse mental health outcomes}

All seven papers in this review commented on predictors of mental health problems, but the central focus remained on pre-migratory factors such as education, personality characteristics and coping mechanisms as well as post-migratory determinants like time since resettlement, social support, employment and language skills.

\section{Personality characteristics and socio-economic} factors

Ghazinour et al. (2003) found that low scores on the Beck Depression Inventory were associated with harm-avoidance, selfdirectedness (sense of individuality) and cooperativeness (being part of a whole) as well as good social support. The latter was highlighted as the most significant correlate to mental health by Carlsson et al. (2006). Their results suggested that the main longterm factors associated with emotional distress and poor quality of life were poor social support $(\mathrm{p}<0.01)$ and unemployment $(p<0.001)$. Also noteworthy is that higher education levels were linked with increased anxiety $(\mathrm{p}<0.05)$.

\section{Physical pain}

Bradley \& Tawfiq (2006) asserted that there was no association between the experience of chronic pain and psychological symptoms. Yet, this was disputed by Carlsson et al. (2006) who investigated survivors who had undergone an initial assessment at a Rehabilitation and Research Centre for Torture Victims (RCT) in Copenhagen from 1991-1994 and then were reassessed ten years later. At follow-up, the study had 139 participants, equaling $63 \%$ of the originally recruited individuals. They maintained that chronic pain was a predictor of mental health problems in the proximity of trauma. However, this predictor was not determinative ten years into resettlement. Morville et al. (2014) also claimed a statistically significant correlation between ADL competency and pain, though the tortured clients did not differ from nontortured groups in terms of both pain and psychopathology.

\section{Time}

Time has been described as a variable that may influence the mental health of refugees. Morville et al. (2014, 2015) showed a decline in ADL-ability as well as an increase in pain and depression over time. In contrast, Carlsson et al. (2006) found that health-related quality of life improved for participants after living in their adopted country for a substantial period of time $(\mathrm{p}<0.01)$. Moreover, after controlling for gender and age, mental health symptoms were significantly less at follow-up $(\mathrm{p}<0.001)$. This mirrors the body of current literature proposing that the proximity of time to exposure to torture is directly linked to depression and PTSD (Steel et al., 2009). Morville et al's (2015) contrary findings can be ascribed to the small sample size as well as the timing of the follow-up which was only ten months after arrival, a period of time that can be argued to still be in the early days of migration.

\section{Gender}

Gender as a predictor was addressed in two papers. In Ghazinour et al's (2003) study, women exposed to trauma were less likely than men to display psychopathological disorders $(\mathrm{p}<0.01)$. Yet, Bradley \& Tawfiq (2006) did not find any correlation between gender and mental health; although women who had been sexually assaulted reported psychological disorders more often, this was not statistically significant. 


\section{Help-seeking behavior}

Lastly, language skills, besides higher levels of PTSD symptoms of arousal and intrusion, emerged as likely predictors of therapyseeking behaviors in Iranian torture survivors (Priebe \& Esmaili, 1997).

\section{Discussion}

Typically, methodologically robust investigations reveal a lower prevalence of psychopathology in tortured refugees than weaker studies. Smaller samples, self-reported questionnaires and point prevalence, rather than period prevalence, produce higher rates of symptoms (Kalt et al., 2013; Johnson \& Thompson, 2008). Further issues are the inter-study heterogeneity in connection with the outcome measures that lack cross-cultural validity. Most studies also suffer from the fact that they were cross-sectional, which carries the major limitation that causal determinants of health cannot be established. There were two thorough record reviews conducted at FFT (Bradley \& Tawfiq, 2006, FFT, 2013). Large variations were still observed. For example, sexual torture had occurred in $60 \%$ of Iranian men and $60 \%$ of Iranian women as opposed to $30 \%$ of Kurdish women and $1 \%$ of Kurdish men. The prevalence rates for health outcomes varied too-PTSD in $14 \%-90 \%$ and chronic pain in $22 \%-48 \%$ of participants - with higher rates reported by Iranian survivors.

It is also remarkable how little research exists on Afghan survivors of torture. In this paper, they were only represented in Morville et al's studies (2014, 2015). Azam Dadfar (1994), who had worked as a psychiatrist in a refugee camp for Afghans in Pakistan from 1987 to 1990 , has documented a prevalence of $51 \%$ for anxiety disorders, PTSD and depression. He also noted substance abuse, mistrust and rage in men and higher vulnerability to psychological and physical suffering in women.

With respect to predictors of mental health, better mental health outcomes were positively associated with social support, language skills, employment and amount of time living in the host country as well certain personality characteristics. An association between physical pain and poor mental health was suspected in the short-term but not the long-term.

Regarding the role that gender and sexual violence play in mental health outcomes, Bradley \& Tawfiq's (2006) findings are consistent with Steel et al's (2009) metaanalysis that did not reveal any statistically significant association between gender and PTSD or depression in traumatised refugees. However, only a small percentage $(15 \%)$ of their participants were women. In contrast, a recent retrospective study undertaken in the U.S. examined the correlation between demographics and type of torture in 235 individuals, and it found that PTSD, anxiety and depression were significantly correlated with rape (Hooberman et al., 2007). Similarly, an association between suicidal ideation and being female or having a history of sexual torture has been illustrated (FFT, 2013; Lerner et al., 2016).

\section{Limitations of the review}

The current study was unable to analyse the grey literature and papers in Turkish and a formal quality assessment of the papers included in the review was not undertaken. Drawing conclusions from the cited studies are also limited because of the small sample size that was biased towards Scandinavian countries. It should also be noted that three out of the seven studies also comprised nationalities other than Iranians, Afghans and Kurds. The same applies to the types of trauma studied as three studies involved 
stressors other than torture. Clearly, such broad metrics will limit the conclusions that can be drawn for victims of torture.

\section{Conclusion}

This literature review set out to examine the health impacts of sexual torture amongst Afghan, Iranian and Kurdish refugees in high-income countries; however, due to the absence of data specifically addressing this form of torture, the review shifted focus to torture in general while still paying close attention to gender and sexual violence as predictors of adverse health outcomes.

Based on the studies in this review, there is a high prevalence of psychological morbidity amongst Afghan, Iranian and Kurdish tortured refugees. Therefore, the most obvious contribution of this paper is the systematic demonstration that there is a dearth of robust research on this population, particularly Afghans. Moreover, despite its reported pervasiveness, sexual torture was not adequately investigated in the reviewed studies. This lack of scholarly attention is consistent with the widespread silence surrounding sexual torture in society. This silence on sexual torture needs to be broken and the urgency is best summarised in a report on sexual torture published by the human rights organisation Justice for Iran, ${ }^{16}$ where the authors point out that: "the public silence in this matter has meant that the victims of sexual torture had to find individual strategies to re-build their lives" (p. 31).

Torture does not occur in a vacuum. Neither is the torture survivor a hollow

16 Crime and Impunity - Sexual Torture of Women in Islamic Republic Prisons (2013). Justice for Iran (pp.31). Retrieved 20 October 2018 from http://www.wluml.org/resource/ crime-and-impunity-sexual-torture-womenislamic-republic-prisons object subjected to a trauma. Similarly, the 'self' is not singular but a fusion of unique positioning and diverse embodied experiences in time and place (Crenshaw, 1991). If health research and clinical practice are to address the needs of the service users, then a more nuanced and critical understanding of the 'cause' and response to suffering is required for. Jefferson (2017) remarks that the fight against torture is usually framed in a medicolegal, human rights, developmental or trauma narrative. This review aims to expand the lens to incorporate epistemologies from postmodern feminist discourse with its distinct conception of gender identity politics and power dynamics. Our theoretical frameworks are crucial because where we locate a problem will impact our priorities, adopted strategies, and resource allocation (Bracken, 2001, pp. 741-2). Therefore, the path towards developing culturally and gendersensitive health research starts with the simple but powerful step of paying deliberate attention to gender, sexuality and culture in the design, data collection and analysis of research. This is feasible with quantitative and qualitative methodologies alike.

\section{Acknowledgments}

I would like to thank Dr Sarah Hawkes and Dr Marta Buszewicz at UCL for their support and feedback on earlier drafts of this paper.

\section{Funding}

NIHR funded my fellowship at the Institute for Global Health, which allowed the work on this review. 


\section{References}

Agger, I. (1989). Sexual torture of political prisoners: An overview. Fournal of Traumatic Stress, 2(3), 305-318. doi:10.1007/bf00976234

Ba, I., \& Bhopal, R. (2017). Physical, mental and social consequences in civilians who have experienced war-related sexual violence: A systematic review (1981-2014). Public Health, 142, 121-135. doi:10.1016/j.puhe.2016.07.019

Basoglu, M. \& Paker, M. (1995). Severity of trauma as predictor of long term psychological status in survivors of torture. Fournal of Anxiety Disorders, 9, 339-350. https://doi. org/10.1016/0887-6185(95)00014-F

Berry, J.W., Poortinga, Y.P., Breugelmans, S.M., Chasiotis, A., Sam, D.L. (1992). Cross-cultural

Psychiatry - Research and Application. Third edition. Cambridge University Press.

Bogic, M., Njoku, A., \& Priebe, S. (2015). Longterm mental health of war-refugees: A systematic literature review. BMC International Health and Human Rights, 15(1). doi:10.1186/s12914-0150064-9

Bracken, P. J. (2001). Post-modernity and post-traumatic stress disorder. Social Science $\mathcal{E} \mathrm{Med}$ icine, 53(6), 733-743. doi:10.1016/s02779536(00)00385-3

Bradley, L., Tawfiq, N. (2006). The physical and psychological effects of torture in Kurds seeking asylum in the United Kingdom. Torture, 16(1), 41-47.

Burt, M. R. (1980). Cultural myths and supports for rape. Fournal of Personality and Social

Psychology, 38(2), 217-230. doi:10.1037//00223514.38.2.217

Busch, J., Hansen, S.H., Hougen, H.P. (2015). Geographical distribution of torture: An

epidemiological study of torture reported by asylum applicants examined at the Department of Forensic Medicine, University of Copenhagen. Torture, 25 (2).

Canning, V. (2015). Unsilencing Sexual Torture: Responses to refugees and asylum seekers in Denmark. British fournal of Criminology, 56(3), 438-455. doi:10.1093/bjc/azv079

Carlsson, J., Olsen, D., Mortensen, E., Kastrup, M. (2006). Mental health and health-related quality of life. The Fournal of Nervous and Mental Disease, 194(10), 725-731.

Crenshaw, K. (1991). Mapping the margins: Intersectionality, identity politics, and violence

against women of color. Stanford Law Review, 43(6), p. 1241 .

Dadfar, A. (1994). The Afghans: Bearing the Scars of a Forgotten War. In A.J. Marsella, T. Bornemann,
S. Ekblad, \& J. Orley (Eds.). Amidst Peril and Pain: The Mental Health and Well-being of the World's Refugees. 125-139. doi:10.1037/10147-006

Duffy, R. M., O’Sullivan, S., Straton, G., Singleton, B., \& Kelly, B. D. (2017). Demographic characteristics of survivors of torture presenting for treatment to a national centre for survivors of torture in Ireland (2001-2012). Irish fournal of Psychological Medicine, 34(2), 111-116. https:// doi.org/10.1017/ipm.2016.32

Freedom From Torture (FFT), (2013). We Will Make You Regret Everything: Torture in Iran Since the 2009 Election. Freedom from Torture Country Reporting.

Ghazinour, M., Richter, J., \& Eisemann, M. (2003). Personality related to coping and social support among Iranian refugees in Sweden. The fournal of Nervous and Mental Disease, 191(9), 595-603. doi:10.1097/01.nmd.0000087186.03513.38

Hollander, A., Bruce, D., Burström, B., \& Ekblad, S. (2011). Gender-related mental health differences between refugees and non-refugee immigrants: A cross-sectional register-based study. BMC Public Health, 11(1). doi:10.1186/1471-2458-11-180

Hooberman, J. B., Rosenfeld, B., Lhewa, D., Rasmussen, A., \& Keller, A. (2007). Classifying the torture experiences of refugees living in the United States. Fournal of Interpersonal Violence, 22(1), 108-123. doi:10.1177/0886260506294999

Isakson, B. L., \& Jurkovic, G. J. (2013). Healing After Torture. Qualitative Health Research, 23(6), 749761. doi:10.1177/1049732313482048

Jefferson, A. M. (2016). Situated perspectives on the global fight against torture. Reflexivity and Criminal Fustice, 335-356. doi:10.1057/978-1137-54642-5_15

Jobson, L. \& Okearney, R. (2008). Cultural differences in personal identity in post-traumatic stress

disorder. British fournal of Clinical Psychology, 47(1), 95-109. doi:10.1348/014466507X235953

Johnson, H., \& Thompson, A. (2008). The development and maintenance of post-traumatic stress disorder (PTSD) in civilian adult survivors of war trauma and torture: A review. Clinical Psychology Review, 28(1), 36-47. doi:10.1016/j. cpr.2007.01.017

Kalt, A., Hossain, M., Kiss, L., \& Zimmerman, C. (2013). Asylum seekers, violence and health: A systematic review of research in high-income host countries. American fournal of Public Health, 103(3), e30-e42. doi:10.2105/ajph.2012.301136

Kastrup, M., Arcel, L. (2004). Gender Specific Treatment. In: Wilson., J., Drozdek, B (Eds.), Broken Spirits: The Treatment of Traumatized Asylum Seekers, Refugees, War and Torture Victims. New York: Brunner Routledge, 547-571. 
Kira, I. A., Smith, I., Lewandowski, L., \& Templin, T. (2010). The effects of gender discrimination on refugee torture survivors: A cross-cultural traumatology perspective. Fournal of the American Psychiatric Nurses Association, 16(5), 299-306. doi:10.1177/1078390310384401

Kira, I. A., \& Tummala-Narra, P. (2014). Psychotherapy with refugees: Emerging paradigm. Fournal of Loss and Trauma, 20(5), 449-467. doi:10.1080/15 325024.2014 .949145

Leaman, S., Gee, C., \& Cogar, M. (2009). Risk factors for psychological distress and uses of religious coping among African torture survivors. PsycEXTRA Dataset. doi:10.1037/e517292011-464

Leatherman, J. (2011). Sexual Violence and Armed Conflict. Cambridge: Polity Press.

Lerner, E., Bonanno, G. A., Keatley, E., Joscelyne, A., \& Keller, A. S. (2016). Predictors of suicidal ideation in treatment-seeking survivors of torture. Psychological Trauma: Theory, Research, Practice, and Policy, 8(1), 17-24. doi:10.1037/ tra0000040

Lunde, I., \& Ortmann, J. (1990). Prevalence and sequelae of sexual torture. The Lancet, 336(8710), 289-291. doi:10.1016/0140-6736(90)91814-q

Matsuo, H., Poljarevic, A. (2011). Life satisfaction of Bosnian refugees in St louis, Missouri. International Fournal of Humanities and Social Science, 1 (19), 30-38.

Morville, A., Amris, K., Eklund, M., DanneskioldSamsøe, B., \& Erlandsson, L. (2014). Activity of daily living performance amongst Danish asylum seekers: a cross-sectional study. Torture. 24(1), 49-64.

Morville, A., Amris, K., Eklund, M., DanneskioldSamsøe, B., \& Erlandsson, L. (2015). A longitudinal study of changes in asylum seekers ability regarding activities of daily living during their stay in the asylum center. Fournal of Immigrant and Minority Health, 17(3), 852-859. doi:10.1007/s10903-014-0004-0

Oosterhoff, P., Zwanikken, P., \& Ketting, E. (2004). Sexual torture of men in Croatia and other conflict situations: An open secret. Reproductive Health Matters, 12(23), 68-77. doi:10.1016/ s0968-8080(04)23115-9

Patel, N., Mahtani, A. (2004). Psychological Approaches to Working with Political Rape. In: M. Peel (Ed.), Rape as a Method of Torture. London: Medical Foundation for the Care of Victims of Torture.

Peel, M. (2004). Men as Perpetrators and Victims. In: M. Peel (Ed.), Rape as a Method of Torture. London: Medical Foundation for the Care of Victims of Torture.
Priebe, S., Ismaili, S. (1997). Long-term mental sequelae of torture in Iran-who seeks treatment? The Fournal of Nervous \& Mental Disease, 185(2), 74-77. doi:10.1097/00005053-199702000-00002

Sansani, I. (2004). Responses by health care providers in Ireland to the experiences of women refugees who have survived gender- and ethnic-based torture. Women's Studies International Forum, 27(4), 351-367. doi:10.1016/j.wsif.2004.10.005

Song, S. J., Kaplan, C., Tol, W. A., Subica, A., \& Jong, J. D. (2014). Psychological distress in torture survivors: Pre- and post-migration risk factors in a U.S. sample. Social Psychiatry and Psychiatric Epidemiology, 50(4), 549-560. doi:10.1007/ s00127-014-0982-1

Steel, Z., Chey, T., Silove, D., Marnane, C., Bryant, R. A., \& Van Ommeren, M. (2009). Association of torture and other potentially traumatic events with mental health outcomes among populations exposed to mass conflict and displacement. $\mathcal{F} A M A, 302(5)$, 537. doi:10.1001/ jama.2009.1132

Suarez, E., \& Gadalla, T. M. (2010). sSop blaming the victim: A meta-analysis on rape myths. Fournal of Interpersonal Violence, 25(11), 2010-2035. doi:10.1177/0886260509354503

Summerfield, D. (1999). A critique of seven assumptions behind psychological trauma

programmes in war-affected areas. Social Science E Medicine, 48(10),1449-1462. doi:10.1016/ S0277-9536(98)00450-X

Weishut, D. J. (2015). Sexual torture of Palestinian men by Israeli authorities. Reproductive Health Matters, 23(46), 71-84. doi:10.1016/j. rhm.2015.11.019

Young, M. Y., Chan, K. J. (2015). The Psychological Experience of Refugees: A Gender and Cultural Analysis. In: S. Safdar \& N. Kosakowska-Berezecka (Eds.), Psychology Of Gender Through The Lens Of Culture: Theories And Applications (pp. 17-36). Cham, Switzerland: Springer International Publishing. 


\section{Appendix 1}

Figure 1: Flow Chart of Study Selection

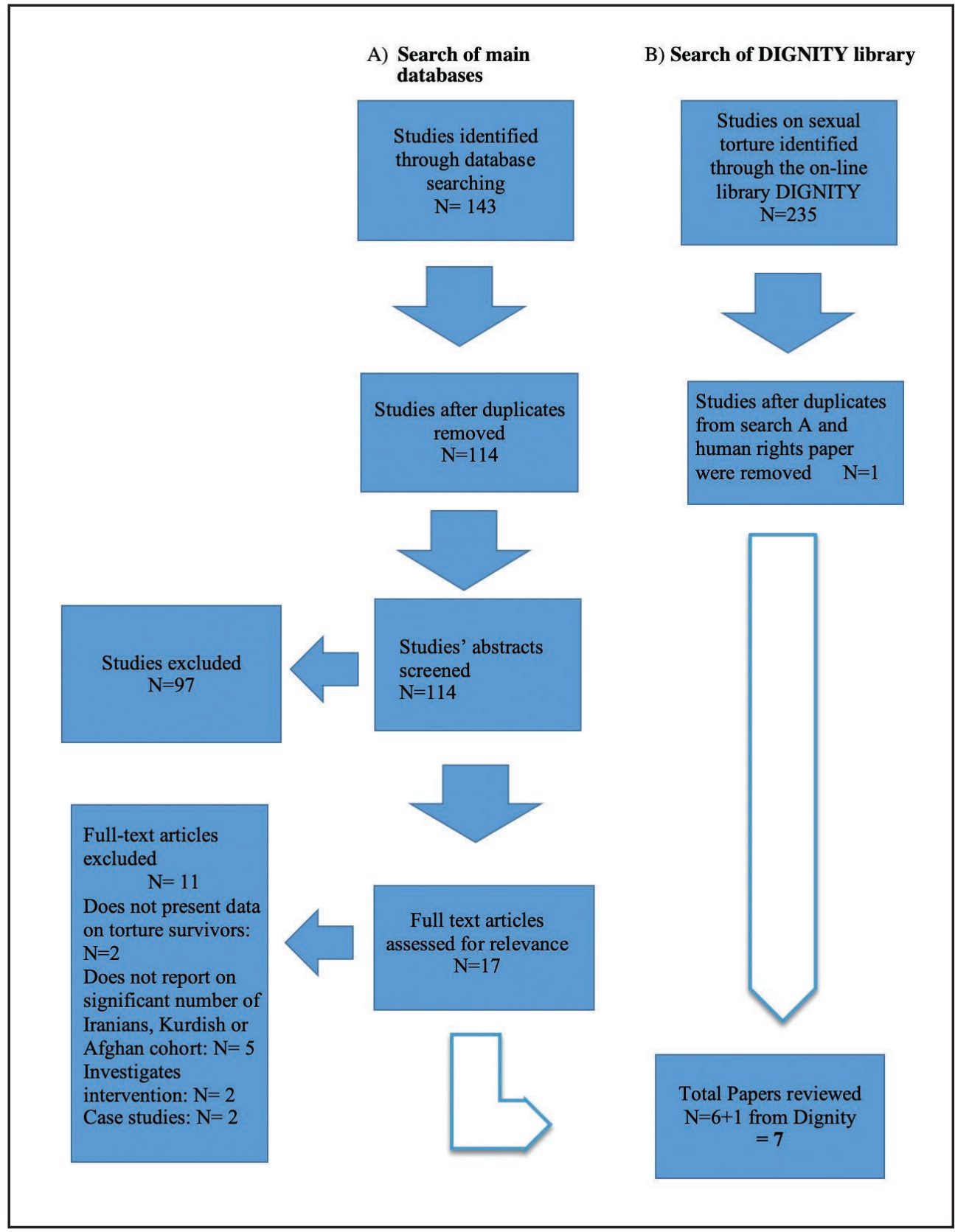

